\title{
Upaya Meningkatkan Hasil Belajar PKn Melalui Model Pembelajaran Kooperatif Tipe Round Club Peserta Didik Kelas IV A SD Negeri 64/IV Kota Jambi
}

\author{
Efda Iryanti \\ SD Negeri 64/IV Kota Jambi \\ Correspondence email: jambiyanti388@gmail.com
}

\begin{abstract}
Research is backed by the fact that PKn is one of the lessons that are lacking in the hearts of learners. Because this learning is considered to be a difficult and boring lesson, it affects the low learning outcomes of learners. Based on observations that authors as teachers in elementary School 64/IV Jambi, especially class IV. A on PKn subjects that students ' learning outcomes are still low. Only 51.85\% of learners reach the KKM 75. This study uses two-cycle class action research. Each cycle consists of four phases: design, activity and observation, reflection, and revision. The target of this research is class IV students. $A$ in SD Negeri 64/IV Jambi City. Data obtained in the form of formative test result, observation sheet of teaching learning activities. From the results analysts gained that student learning results experienced an increase from the pre cycle until the II cycle, the precycle (64.81\%) With the submission of 51.85, Cycle I (72.41\%), with 70.37 and cycle II (80.93\%) With the 85.19 submission. The conclusion of this study is the cooperative learning Model of Round Club type can positively affect the outcome of students learning outcomes of class IV. A State Elementary School 64/IV Jambi City, and this learning model can be used as an alternative learning of PKn.
\end{abstract}

Keywords: PKn, cooperative learning Model Round Club type.

\section{PENDAHULUAN}

Pendidikan Kewarganegaraan (PKn) diberikan sejak SD sampai SLTA. Dengan PKn seseorang akan memiliki kemampuan untuk mengenal dan memahami karakter dan budaya bangsa serta menjadikan warga negara yang siap bersaing di dunia internasional tanpa meninggalkan jati diri bangsa. Melalui PKn setiap warga negara dapat mawas diri dengan perkembangan teknologi informasi dan komunikasi dewasa ini yang memberi dampak positif dan negatif. PKn juga bermanfaat untuk membekali peserta didik agar memiliki kemampuan untuk mengelola dan memanfaatkan informasi untuk bertahan hidup pada keadaan yang selalu berubah, tidak pasti dan kompetitif.

Pendidikan nasional berdasarkan Pancasila bertujuan untuk meningkatkan kualitas manusia Indonesia, yaitu manusia yang beriman dan bertakwa terhadap Tuhan Yang Maha Esa, berbudi pekerti luhur, berkepribadian, berdisiplin, bekerja keras, tangguh, bertanggungjawab, mandiri, cerdas dan terampil serta sehat jasmani dan rohani. Pendidikan nasional juga harus mampu menumbuhkan dan memperdalam rasa cinta pada tanah air, mempertebal semangat kebangsaan dan rasa kesetiakawanan sosial. Dalam dunia pendidikan kita sering mendengar ungkapan yang cukup sederhana yaitu "mendidik anak pada masa kini berarti menyiapkan orang dewasa di masa mendatang". Pendidik harus bisa menyiapkan anak didik menjadi orang dewasa yang mandiri, mampu menggunakan dan mengembangkan sendiri kemampuan (pengetahuan dan keterampilan) yang telah dimilikinya, dan mempunyai sikap yang sesuai dengan norma-norma yang berlaku di masyarakat.

Pendidikan Pancasila dan Kewarganegaraan yang sesuai dengan isi Kurikulum 2004 adalah pendidikan tentang nilai-nilai yang sasarannya bukan semata-mata pengalihan pengetahuan melainkan lebih ditekankan pada pembentukan sikap. Dengan demikian mata pelajaran PKn meliputi ranah kognitif, afektif dan psikomotor, yang lebih menitikberatkan pada ranah afektif.
Dalam proses pembelajaran PKn, guru belum semuanya melaksanakan pendekatan siswa aktif, dan peranan guru sebagai dinamisator belajar siswa belum diterapkan, namun guru masih dominan menggunakan metode ceramah dan tanya jawab. Dalam penyampaian materi pelajaran guru masih menggunakan buku-buku sumber dan buku pelengkap sebagai sumber belajar, dan dalam penyampaian bahan ajar kepada siswa belum digunakan media belajar yang lain.

Oleh sebab itu pendidikan perlu dikembangkan secara menyeluruh mulai dari segai para pendidik, fasilitas, pendekatan, media, serta model pembelajarannya. Sehingga aktif. Aitas pendidikan menjadi maksimal.

Guru yang menjadi salah satu komponen tersebut dalam usaha meningkatkan kualitas pendidikan, memiliki peran sebagai informator, organisator, motifator, fasilitator, mediator, inisiator, dan evaluator bagi peserta didik, sehingga peserta didik dapat mencapai tujuan pendidikan secara maksimal.

Memperhatikan peranan guru yang begitu penting dalam peningkatan mutu pendidikan, maka dibutuhkan guru yang mempunyai rasa pengabdian yang tinggi serta tanggung jawab yang besar, yang dapat dilihat dari loyalitasnya terhadap tugas, menyenangi pekerjaan dan mempunyai motivasi kerja yang tinggi. Didalam menjalankan peranannya guru memiliki tanggung jawab untuk membawa para peserta didik pada kematangan tertentu yang dilaksanakan pada proses pembelajaran.

Proses pembelajaran adalah aktifitas belajar yang dilaksanakan oleh para peserta didik dan mengajar dilaksanakan oleh guru (pendidik). Chatlijah (1994) menyatakan "Belajar adalah suatu aktifitas mental dan psikis yang yang berlangsung dalam interaksi aktif dengan lingkungan yang menghasilkan perubahanperubahan dalam pengetahuan, keterampilan dan nilai sikap "selain itu mengajar adalah suatu aktifitas mengorganisasi (mengatur) lingkungan sebaik-baiknya dan menghubungkannya dengan para peserta didik sehingga terjadi interaksi. Baik atau buruknya suatu proses pembelajaran menyangkut tiga hal yakni: 
1. Prilaku, persyaratan, kualifikasi, fungsi dan tugas yang harus dipenuhi dan dilaksanakan oleh guru (pendidik).

2. Minat, bakat, karakter serta masalah-masalah yang dihadapi para peserta didik yang wajib diperhatikan oleh guru (pendidik).

3. Tujuan pembelajaran, bahan, metode, media, dan evaluasi serta rencana pembelajaran yang harus dirumuskan atau disusun dan dilaksanakan oleh setiap guru (pendidik).

Begitu pentingnya keaktifan para peserta didik dalam mencapai tujuan pendidikan dan proses pembelajaran yang telah ditetapkan. Hal ini dapat dilihat dari uraian di atas bahwa proses pembelajaran berkaitan erat dengan guru (pendidik), para peserta didik dan kurikulum yang telah ditetapkan. Selama proses pembelajaran berlangsung interaksi antara guru (pengajar) dengan para peserta didik harus dapat diciptakan kondisi kelas semaksimal mungkin agar tujuan yang diinginkan dapat terlaksana.

Didalam pelaksanaan proses pembelajaran, para peserta didik yang melakukan proses pembelajaran tersebut banyak mengalami kesulitan serta mengalami berbagai macam masalah yang dihadapinya. Hal ini terjadi karena adanya hal-hal serta kondisi yang memaksa para peserta didik tersebut tidak termotivasi demi perkembangan sikap dan kepribadiannya dalam proses pembelajaran. Dimana faktor penyebab dari permasalahan di atas bisa timbul baik dari dalam diri para peserta didik maupun dari luar diri para peserta didik. Dimana, faktor yang berasal dari dalam diri para peserta didik tersebut yang berkaitan diantaranya pribadi para peserta didik secara psikologi, adanya tingkah laku yang disebabkan oleh faktor keturunan atau potensipotensi dari organisme serta pengalaman belajar yang pernah dilalui sebelumnya. Selanjutnya, faktor yang berasal dari luar diri para peserta didik bisa disebabkan oleh lingkungan yang kurang kondusif, suasana dan situasi kelas, alat dan media pendidikan yang tidak mendukung, dan sebagainya.

Pembelajaran PKn sebagai pembelajaran yang mampu mengantarkan peserta didik mengembangkan kepribadiannya menjadi warga negara yang baik dan menimbulkan kebiasaan.

Tetapi kenyataannya PKn merupakan salah satu pelajaran yang kurang mendapatkan tempat dihati peserta didik. Karena pembelajaran ini di anggap pelajaran sulit dan membosankan sehjingga berdampak pada rendahnya hasil belajar peserta didik. Berdasarkan pengamatan yang penulis sebagai guru di SD Negeri 64/IV Jambi, khususnya Kelas IV.A pada mata pelajaran PKn bahwa hasil belajar para peserta didik masih rendah. Hanya $51,85 \%$ saja peserta didik yang mencapai KKM 75.

Untuk mengatasi hal tersebut perlu diupayakan langkah-langkah yang dapat dilaksanakan baik oleh peserta didik maupun guru. Bentuk dari tindakan guru dalam upaya meningkatkan hasil belajar peserta didik ini diwujudkan dengan memilih Model pembelajaran kooperatif tipe Round Club.

Model pembelajaran round club adalah pembelajaran berkelompok untuk bekerjasama saling membatu mengkontruksi konsep. Model pembelajaran ini menuntut tanggung jawab masing-masing anggota kelompok untuk turut serta berkontribusi aktif di dalam kelompok dan memikirkan pendapat anggota lain. dengan keunggulan model pembelajaran round club mampu meningkatkan hasil belajar peserta didik yang rendah khususnya pada mata pelajaran PKn.

\section{Landasan Teori Belajar}

Menurut pandangan tradisional dalam Hanafiah dkk (2009:6) belajar adalah usaha memperoleh sejumlah ilmu pengetahuan, dimana belajar lebih berorientasi pada pengembangan intelektualitas atau pengembangan otak, knowledge is power, yaitu barang siapa yang menguasai pengetahuan maka dia akan mendapat kekuasaan. Oleh karena itu, bahan bacaan merupakan sumber atau kunci utama untuk memperoleh ilmu pengetahuan

Menurut Witherington (1952:165) dalam Hanafiah dkk (2009:7) yang menyatakan bahwa belajar merupakan perubahan dalam kepribadian yang dimanifestasikan sebagai pola-pola respon baru yang berbentuk keterampilan, sikap, kebiasaan, pengetahuan dan kecakapan.

Belajar menurut Gagne, berlener, dan Hilgard (1970:256) dalam Hanafiah dkk (2009:7) adalah suatu proses perubahan perilaku yang muncul karena pengalaman. Sedangkan menurut Bell-Gredler dalam Udin S. Winataputra (2008) pengertian belajar adalah proses yang dilakukan oleh manusia untuk mendapatkan aneka ragam competencies, skills, and attitude. Kemampuan (competencies), keterampilan (skills), dan sikap (attitude) tersebut diperoleh secara bertahap dan berkelanjutan mulai dari masa bayi sampai masa tua melalui rangkaian proses belajar sepanjang hayat.

Menurut Oemar Hamalik (2001: 28), belajar adalah "Suatu proses perubahan tingkah laku individu melalui interaksi dengan lingkungan"

Aspek tingkah laku tersebut adalah: pengetahuan,pengertian, kebiasaan, keterampilan, apresiasi, emosional, hubungan sosial, jasmani, etis ataubudi pekerti dan sikap.

Sedangkan, Sardiman A.M. (2003 : 22) menyatakan: "Belajar merupakan suatu proses interaksi antara diri manusia dengan lingkungannya yang mungkin berwujud pribadi, fakta, konsep ataupun teori.

Berdasarkan dari beberapa pengertian belajar diatas dapat disimpulkan belajar adalah proses perubahan perilaku, berkat interaksi dengan lingkungannya. Perubahan perilaku mencakup aspek kognitif, afektif dan psikomotor. Adapun yang dimaksud lingkungan mencakup keluarga, sekolah dan masyarakat, di mana peserta didik berada.

Ciri-ciri belajar adalah :

a. Belajar harus memungkinkan terjadinya perubahan perilaku pada diri individu. Perubahan tersebut tidak hanya pada aspek pengethauan atau kognitif saja tetapi juga meliputi aspek sikap dan nilai (afektif) serta keterampilan (psikomotor).

b. perubahan itu merupakan buah dari pengalaman. Perubahan perilaku yang terjadi pada individu karena 
adanya interaksi antara dirinya dengan lingkungan . interaksi ini dapat berupa interaksi fisik dan psikis.

c. perubahan perilaku akibat belajar akan bersifat cukup permanen.

\section{Prinsip-prinsip Belajar}

Prinsip-prinsip dalam belajar Dimyanti dan Mudjiono dalam Aminudin (2011: 15) diantaranya adalah sebagai berikut:

a. Perhatian dan motivasi

Perhatian dan motivasi mempunyai peranan yang penting dalam kegiatan belajar. Dari kajian teori belajar pengolahan informasi terungkap bahwa tanpa adanya perhatian tak mungkin terjadi belajar. Sedangkan motivasi adalah tenaga yang menggerakkan aktivitas seseorang. Motivasi dapat dibandingkan dengan mesin dan kemudi pada mobil.

b. Keaktifan

Belajar hanya mungkin terjadi apabila anak aktif mengalami sendiri. Menurut John Dewey misalnya mengemukakan, bahwa belajar menyangkut apa yang harus dikerjakan mahapeserta didik untuk dirinya, maka inisiatif harus datang dari peserta didik sendiri.

c. Keterlibatan langsung/berpengalaman

Belajar harus dilakukan sendiri/mengalami sendiri tanpa dilimpahkan ke orang lain. Menurut Edgar Dale dalam pengalamannya mengemukakan bahwa belajar yang paling baik adalah belajar melalui pengalaman langsung.

d. Pengulangan

Prinsip belajar yang menekankan perlunya pengulangan dikemukakan oleh teori Psikologi Daya dan menurut teori ini belajar adalah melatih dayadaya yang ada pada manusia yang terdiri atas daya pengamat, menanggap, mengingat, mengkhayal, merasakan, berpikir dan sebagainya.

Menurut Thorndike mengemukakan bahwa belajar adalah pembentukan hubungan antara stimulus dan respons dan pengulangan terhadap pengalamanpengalaman itu memperbesar peluang timbulnya respons yang benar.

e. Tantangan

Teori Medan (Field Theory) dari Kurt Lewin mengemukakan bahwa peserta didik dalam situasi belajar berada dalam suatu medan atau lapangan psikologis. Dalam situasi belajar peserta didik menghadapi suatu tujuan yang ingin dicapai, tetapi selalu terdapat hambatan yaitu mempelajari bahan belajar, maka muncullah motif untuk mengatasi hambatan itu yaitu dengan mempelajari bahan belajar tersebut. Apabila hambatan itu dapat diatasi berarti tujuan belajar telah tercapai, maka ia akan masuk dalam medan baru, tujuan baru dan seterusnya.

f. Balikan dan penguatan

Menurut Thorndike, peserta didik akan belajar lebih bersemangat apabila mengetahui dan mendapatkan hasil yang baik. Hasil belajar yang baik akan, akan merupakan balikan yang menyenangkan dan berpengaruh baik bagi usaha belajar selanjutnya. Namun dorongan belajar itu menurut B.F. Skiner tidak saja oleh penguatan yang menyenangkan tetapi juga yang tidak menyenangkan, atau dengan kata lain penguatan positif maupun negatif dapat memperkuat belajar.

g. Perbedaan individual

Peserta didik merupakan individual yang unik artinya tidak ada dua orang yang sama persis, setiap peserta didik memiliki perbedaan satu dengan yang lainnya.

\section{Hasil Belajar}

Tujuan belajar meliputi bertambahnya pengetahuan dan keterampilan, sehingga pencapaian tujuan belajar adalah memperoleh hasil belajar yang baik. Oleh karena itu sebagai pendidik harus dapat menyampaikan tujuan belajar dengan baik.

Untuk mengetahui sejauh mana proses belajar mengajar mencapai tujuan pembelajaran yang diharapkan, maka perlu diadakan tes hasil belajar. Menurut pendapat Winata Putra dan Rosita (1997; 191 ) tes hasil belajar adalah salah satu alat ukur yang paling banyak digunakan untuk menentukan keberhasilan seseorang dalam suatu proses belajar mengajar atau untuk menentukan keberhasilan suatu program pendidikan. Adapun dasar-dasar penyususan tes hasil belajar adalah sebagai berikut:

a. Tes hasil belajar harus dapat mengukur apa-apa yang dipelajari dalam proses pembelajaran sesuai dengan tujuan instruksional yang tercantum dalam kurikulum yang berlaku.

b. Tes hasil belajar disusun sedemikian sehingga benar-benar mewakili bahan yang telah dipelajari.

c. Bentuk pertanyaan tes hasil belajar hendaknya disesuaikan dengan aspek-aspek tingkat belajar yang diharapkan.

d. Tes hasil belajar hendaknya dapat digunakan untuk memperbaiki proses belajar mengajar.

Tabrani (1992;3) mengatakan bahwa belajar mengajar adalah suatu proses yang rumit karena tidak sekedar menyerap informasi dari guru, tetapi melibatkan berbagai kegiatan maupun tindakan yang harus dilakukan , terutama bila diinginkan hasil yang lebih baik

\section{Model Pembelajaran Round Club atau Keliling Kelompok}

Model Pembelajaran Round Club Atau Keliling Kelompok adalah kegiatan pembelajaran dengan cara berkelompok untuk bekerjasama saling membantu mengkontruksi konsep. Menyelesaikan persoalan atau inkuiri. Menurut teori dan pengalaman agar kelompok kohesif (kompak-partisipatif), tiap anggota kelompok terdiri dari 4-5 orang, peserta didik heterogen (kemampuan gender, karakter) ada control dan fasilitasi, serta meminta tanggung jawab hasil kelompok berupa laporan atau presentasi. Model pembelajaran ini dimaksudkan agar masing-masing anggota kelompok mendapat serta pemikiran anggota lain.

\section{METODE PENELITIAN Jenis Penelitian}

Penelitian ini termasuk dalam jenis penelitian tindakan kelas (PTK). Ciri utama dari penelitian tindakan kelas yakni adanya tindakan-tindakan tertentu untuk memperbaiki dan menyempurnakan proses 
pembelajaran di kelas. Penelitian tindakan kelas yang digunakan adalah penelitian partisipan di mana peneliti terlibat secara langsung dan penuh dalam penelitian mulai dari awal sampai akhir penelitian.

\section{Lokasi dan Waktu Penelitian \\ Lokasi Penelitian}

Penelitian ini dilaksanakan di SD Negeri 64/IV Jambi, dipilihnya sekolah ini sebagai tempat meneliti karena peneliti adalah sebagai guru mata pelajaran PKn di SD tersebut. Adapun alamat SD Negeri 64/IV adalah terletak di jalan Ir.H.Juanda Kartawijaya Simpang III Sipin Kota Baru, Kota Jambi

\section{Waktu Penelitian}

Adapun waktu penelitian ini dilaksanakan pada bulan Agustus sampai dengan bulan Oktober tahun pelajaran 2016/2017.

\section{Subjek Penelitian}

Subjek yang dimaksud tindakan dalam penelitian ini adalah peserta didik kelas V.B SD Negeri 64/IV Jambi yang berjumlah 27 peserta didik terdiri dari 13 perempuan dan 14 laki-laki. Subjek tersebut merupakan peserta didik kelas IV.A ganjil tahun pelajaran 2016/2017, sedangkan partisipan yang terlibat dalam penelitian ini adalah guru kelas dan teman sejawat lainnya.

\section{Indikator Ketercapaian}

Indikator ketercapaian penelitian ini menggunakan nilai hasil pembelajaran peserta didik saat melaksanakan siklus I dan II, yakni apabila secara klasikal $85 \%$ peserta didik kelas IV.A SD Negeri 64/IV Jambi yang telah memperoleh nilai minimal 75 (KKM tergantung sekolah) pada mata pelajaran PKn dengan materi mendeskripsikan Negara Kesatuan Republik Indonesia.

\section{Prosedur Penelitian}

Penelitian ini menggunakan metode penelitian tindakan kelas (PTK). Hal ini disesuaikan dengan karakeristik penelitian tindakan kelas, yaitu masalah yang harus dipecahkan berasal dari persoalan praktik pembelajaran di kelas atau berangakat dari permasalahan praktik faktual. Model penelitian tindakan kelas ini merujuk pada model Kemmis dan MC Taggart yang menguraikan bahwa tindakan yang digambarkan sebagai suatu proses yang dinamis dari aspek perencanaan, tindakan (pelaksanaan), observasi (pengamatan), refleksi.

\section{Teknik dan Alat Pengumpulan Data}

Pengumpulan data dalam penelitian ini dilakukan dengan menggunakan teknik catatan lapangan, lembar kerja peserta didik, tes tertulis, dan dokumen. Teknik pengumpulan data secara rinci adalah sebagai berikut : Lembar Kerja Peserta didik

Lembar kerja peserta didik ini digunakan untuk mengetahui keterampilan proses dan sikap para peserta didik dalam proses belajar mengajar dengan menggunakan model pembelajaran kooperatif tipe round club yang dapat dilihat dari keterampilan peserta didik dalam mengamati, serta melakukan percobaan yang telah dilakukan dan melaporkan hasil pada lembar kerjanya dan keaktifan dalam mengajukan pertanyaan dan dapat menarik kesimpulan dari percobaan yang telah dilakukan.

Tes

Tes ini digunakan untuk mengetahui sejauh mana daya tangkap peserta didik dan mengukur kemampuan peserta didik baik kemampuan awal, perkembangan dan kemampuan pada akhir siklus tindakan. Dan tes ini digunakan untuk mendapatkan data tentang hasil belajar peserta didik, tes yang digunakan adalah tes tertulis yang dianalisis dengan membuat tes formatif yang kemudian dibuat prosentasenya untuk mengetahui ketuntasan belajar peserta didik dalam pembelajaran PKn.

Observasi

Digunakan untuk mendapatkan informasi tentang aktivitas guru dan peserta didik dalam proses pembelajaran.

\section{Bukti dokumentasi}

Digunakan untuk memperoleh bukti jalannya proses pembelajaran PKn dengan metode berupa fotofoto.

\section{Teknik Analisis Data}

Untuk mengetahui keefektivan suatu metode dalam kegiatan pembelajaran perlu diadakan analisa data. Pada penelitian ini menggunakan teknik analisis deskriptif kualitatif, yaitu suatu metode penelitian yang bersifat menggambarkan kenyataan atau fakta sesuai dengan data yang diperoleh dengan tujuan untuk mengetahui hasil belajar yang dicapai peserta didik juga untuk memperoleh respon peserta didik terhadap kegiatan pembelajaran.

Untuk menganalisis tingkat keberhasilan atau persentase keberhasilan peserta didik setelah proses belajar mengajar setiap putarannya dilakukan dengan cara memberikan evaluasi berupa soal tes tertulis pada setiap akhir putaran.

Analisis ini dihitung dengan menggunakan statistik sederhana yaitu:

\section{Untuk menilai ulangan atau tes formatif}

Peneliti melakukan penjumlahan nilai yang diperoleh peserta didik, yang selanjutnya dibagi dengan jumlah peserta didik yang ada di kelas tersebut sehingga diperoleh rata-rata tes formatif dapat dirumuskan:

$\bar{X}=\frac{\sum X}{\sum N}$

Dengan:

$\bar{X} \quad=$ Nilai rata-rata

$\Sigma X \quad=$ Jumlah semua nilai peserta didik

$\Sigma \mathrm{N}=$ Jumlah peserta didik

\section{Untuk ketuntasan belajar}

Ada dua kategori ketuntasan belajar yaitu secara perorangan dan secara klasikal. Berdasarkan petunjuk pelaksanaan belajar mengajar di SD Negeri 64/IV Jambi, yaitu seorang peserta didik telah tuntas belajar bila telah mencapai skor $75 \%$ atau nilai 75 , dan kelas disebut tuntas belajar bila di kelas tersebut terdapat $85 \%$ yang telah mencapai daya serap lebih dari atau sama dengan 
$75 \%$. Untuk menghitung persentase ketuntasan belajar digunakan rumus sebagai berikut:

$$
P=\frac{\sum \text { peserta } . \text { didik.yang } \text {.tuntas .belajar }}{\sum \text { peserta } \cdot \text { didik }} \times 100 \%
$$

\section{Untuk lembar observasi}

Untuk menghitung lembar observasi pengelolaan model pembelajaran kooperatif tipe round club digunakan rumus sebagai berikut:

$\bar{X}=\frac{P_{1}+P_{2}}{2}$

Dimana:

$\mathrm{P}_{1} \quad=$ pengamat 1

$\mathrm{P}_{2} \quad$ = pengamat 2

\section{HASIL DAN PEMBAHASAN}

\section{Gambaran Umum Lokasi Penelitian}

Gambaran umum lokasi penelitian tindakan kelas ini adalah di SD Negeri 64/IV Kota Jambi. Alamat sekolah tersebut terletak di Jalan Ir.H.Juanda Kartawijaya Simpang III Sipin Kota Baru, Kota Jambi. Adapun akreditasi sekolah adalah A yang didirikan pada tahun 1977 dan beroperasi pada tahun 1980 dengan luas tanah 4.572M dengan luas bangunan 669M.. Status bangunan merupakan milik Pemda Kota Jambi.

Rombongan belajar SD Negeri 64/IV Kota Jambi sebanyak 885 Kelas, 1 ruang kepala sekolah, dan 1 ruang perpustakaan, 1 ruang Majelis guru, 1 ruang perpustakaan, 1 ruang UKS. WC dan Mussholah I buah. Jumlah guru PNS 25 orang, 7 orang guru honor sekolah. Berdasarkan dari data jumlah guru yang PNS saja menunjukkan bahwa sekolah tersebut jumlah guru dan ruang kelasnya sudah menunjukkan sekolah besar.

\section{Gambaran Umum Subjek Penelitian}

Gambaran umum subjek penelitian ini adalah siswa kelas IV.A SD Negeri 64/IV Kota Jambi yang berjumlah sebanyak 27 orang yang terdiri dari 14 lakilaki dan 13 perempuan. Kondisi siswa sebelum dilakukan penelitian tindakan kelas bahwa hasil belajarnya dengan rata-rata ulangan hariannya adalah 59,75 dari jumlah siswa sebanyak 27 orang.

Pra siklus merupakan kondisi awal peserta didik sebelum peneliti melakukan kegiatan penelitian di dalam kelas dengan menggunakan pola pembelajaran konvensional atau teacher center. Selanjutnya berdasarkan hasil data pra siklus yang diperoleh melalui hasil ulangan harian peserta didik sebelumnya, terlihat masih rendahnya hasil belajar yang dicapai peserta didik tersebut. Hal ini dikarenakan proses pembelajaran yang terjadi bersifat monoton dan hanya berpusat pada guru. Sehingga tingkat partisipasi peserta didik dalam belajar masih rendah dan peseta didik kurang bersemangat dalam belajar.

Sebelum dilakukan penelitian tindakan perbaikan, di awal peneliti sebagai guru mengajar mata pelajaran PKn dalam melaksanakan pembelajaran masih berpusat pada guru, belum menggunakan metode, teknik, dan strategi yang tepat untuk pencapaian indikator dan kompetensi dasar pembelajaran. Pada kondisi ini terlihat para peserta didik kurang bersemangat dalam belajar, sehingga masih terlihat peserta didik yang tidak memperhatikan ketika guru menerangkan di depan kelas dengan mengobrol dengan sesama peserta didik lainnya. Hal ini berdampak pada hasil belajar peserta didik yang rendah, yang dapat di lihat pada tabel di bawah ini:

Tabel 1. Nilai Tes Formatif Pada Pra siklus

\begin{tabular}{|c|c|c|}
\hline $\begin{array}{c}\text { No. } \\
\text { Urut }\end{array}$ & Nilai & Keterangan \\
\hline \hline 1 & 50 & Tidak Tuntas \\
\hline 2 & 50 & Tidak Tuntas \\
\hline 3 & 75 & Tuntas \\
\hline 4 & 60 & Tidak Tuntas \\
\hline 5 & 50 & Tidak Tuntas \\
\hline 6 & 75 & Tuntas \\
\hline 7 & 75 & Tuntas \\
\hline 8 & 60 & Tidak Tuntas \\
\hline 9 & 75 & Tuntas \\
\hline 10 & 75 & Tuntas \\
\hline 11 & 65 & Tidak Tuntas \\
\hline 12 & 50 & Tidak Tuntas \\
\hline 13 & 75 & Tuntas \\
\hline 14 & 75 & Tuntas \\
\hline
\end{tabular}

\begin{tabular}{|c|c|c|}
\hline $\begin{array}{c}\text { No. } \\
\text { Urut }\end{array}$ & Nilai & Keterangan \\
\hline \hline 15 & 80 & Tuntas \\
\hline 16 & 75 & Tuntas \\
\hline 17 & 50 & Tidak Tuntas \\
\hline 18 & 75 & Tuntas \\
\hline 19 & 75 & Tuntas \\
\hline 20 & 75 & Tuntas \\
\hline 21 & 60 & Tidak Tuntas \\
\hline 22 & 40 & Tidak Tuntas Tuntas \\
\hline 23 & 55 & Tidak Tuntas \\
\hline 24 & 60 & Tuntas \\
\hline 25 & 80 & Tuntas \\
\hline 26 & 75 & Tidak Tuntas \\
\hline 27 & 40 & \\
\hline
\end{tabular}

\section{Jumlah Nilai $=1750$ \\ Jumlah Nilai Maksimal Ideal $=2700$ \\ Rata-Rata Skor Tercapai $=68,33$}

Keterangan:

Jumlah peserta didik yang belum tuntas $=13$

Jumlah peserta didik yang tuntas $=14$

Klasikal $=$ Belum Tuntas 
Tabel 2. Rekapitulasi Hasil Tes Formatif Pada Pra Siklus

\begin{tabular}{|c|l|c|}
\hline No. & \multicolumn{1}{|c|}{ Uraian } & Hasil Pra Siklus \\
\hline \hline 1. & Nilai rata-rata tes formatif & 64,81 \\
\hline 2. & Jumlah peserta didik yang tuntas belajar & 14 \\
\hline 3. & Persentase ketuntasan belajar & 51,85 \\
\hline
\end{tabular}

Dari tabel di atas dapat dijelaskan bahwa sebelum menerapkan model pembelajaran kooperatif tipe Round club diperoleh nilai rata-rata hasil belajar peserta didik adalah 64,81 dan ketuntasan belajar mencapai $51,85 \%$ atau ada 14 peserta didik dari 27 peserta didik sudah tuntas belajar. Hasil tersebut menunjukkan bahwa pada prasiklus secara klasikal peserta didik belum tuntas belajar, karena peserta didik yang memperoleh nilai $\geq 75$ hanya sebesar $51,85 \%$ lebih kecil dari persentase ketuntasan yang dikehendaki yaitu sebesar $85 \%$ dalam proses pembelajaran $\mathrm{PKn}$.

Untuk itu peneliti dengan di bantu teman sejawat berupaya melakukan tindakan perbaikan guna meningkatkan hasil belajar PKn dengan mencari metode pembelajaran yang dianggap tepat. Berdasarkan hasil diskusi kecil dengan teman sejawat maka ditentukanlah model pembelajaran kooperatif tipe round club yang akan digunakan dalam proses tindakan perbaikan pembelajaran PKn yang diharapkan dapat meningkatkan hasil belajar PKn yang pelaksanaannya akan dilaksanakan dalam 2 siklus.

\section{Siklus I \\ Tahap Perencanaan}

Pada tahap ini peneliti mempersiapkan perangkat pembelajaran yang terdiri dari rencana pelajaran I, LKPD I, soal tes formatif I dan alat-alat pengajaran yang mendukung. Selain itu juga dipersiapkan lembar observasi pengolahan model pembelajaran kooperatif tipe Round club.

\section{Tahap Kegiatan dan Pelaksanaan}

Pelaksanaan kegiatan belajar mengajar untuk siklus I dilaksanakan pada tanggal 21 dan 28 September 2017 di kelas IV.A dengan jumlah peserta didik 27 peserta didik. Dalam hal ini peneliti bertindak sebagai guru. Adapun proses belajar mengajar mengacu pada rencana pelajaran yang telah dipersiapkan. Pengamatan (observasi) dilaksanakan bersamaan dengan pelaksaaan belajar mengajar.

Tabel 3. Pengelolaan Pembelajaran Pada Siklus I

\begin{tabular}{|c|c|c|c|c|}
\hline \multirow{2}{*}{ No. } & \multirow{2}{*}{ Aspek Yang diamati } & \multicolumn{2}{|c|}{ Penilaian } & \multirow{2}{*}{ Rata-Rata } \\
\hline & & P1 & $\mathrm{P} 2$ & \\
\hline \multirow{14}{*}{ I. } & $\begin{array}{l}\text { Pengamatan KBM } \\
\text { A. Pendahuluan }\end{array}$ & & & \\
\hline & 1. Memotivasi peserta didik & 3 & 3 & 3 \\
\hline & 2. Menyampaikan tujuan pembelajaran & 3 & 4 & 3,5 \\
\hline & 3. Menghubungkan dengan pelajaran sebelumnya & 2 & 3 & 2,5 \\
\hline & 4. Mengatur peserta didik dalam kelompok-kelompok belajar & 1 & 3 & 2 \\
\hline & B. Kegiatan inti & & & \\
\hline & 1. Mempresentasikan langkah-langkah metode pembelajaran kooperatif & 1 & 2 & 1,5 \\
\hline & 2. Membimbing peserta didik melakukan kegiatan & 2 & 2 & 2 \\
\hline & 3. Melatih keterampilan kooperatif & 2 & 3 & 2,5 \\
\hline & 4. Mengawasi setiap kelompok secara bergiliran & 3 & 3 & 3 \\
\hline & 5. Memberikan bantuan kepada kelompok yang mengalami kesulitan & 3 & 3 & 3 \\
\hline & C. Penutup & & & \\
\hline & 1. Membimbing peserta didik membuat rangkuman & 2 & 2 & 2 \\
\hline & 2. Memberikan evaluasi & 2 & 3 & 2,5 \\
\hline II. & Pengelolaan Waktu & 3 & 3 & 3 \\
\hline \multirow{3}{*}{ III. } & Antusiasme Kelas & & & \\
\hline & 1. Peserta didik antusias & 3 & 3 & 2 \\
\hline & 2. Guru antusias & 2 & 3 & 2,5 \\
\hline \multicolumn{2}{|r|}{ Jumlah } & 32 & 40 & 36 \\
\hline & Keterangan: & $\begin{array}{c}\text { Nilai } \\
1 \\
2 \\
3 \\
4\end{array}$ & \multicolumn{2}{|c|}{$\begin{array}{l}\text { Kriteria } \\
\text { Tidak Baik } \\
\text { Kurang Baik } \\
\text { Cukup Baik } \\
\text { Baik }\end{array}$} \\
\hline
\end{tabular}

Pada akhir proses belajar mengajar peserta didik diberi tes formatif I dengan tujuan untuk mengetahui tingkat keberhasilan peserta didik dalam proses belajar mengajar yang telah dilakukan. Adapun data hasil penelitian pada siklus I adalah seperti yang terlihat pada tabel 3.
Berdasarkan mempersentasikan pembelajaran kooperatif, adalah sebagai berikut: 1) mengatur peserta didik dalam kelompok(2), 2) Mempresentasekan langkah-langkah model pembelajaran kooperatif Round Club (1,5) 3) Membimbing peserta diidk melakukan kegiatan (2), dan 
4) membimbing peserta didik membuat rangkuman(2) yang mendapat kriteria kurang baik. Adapun hasil skor total pengelolaan pembelajaran guru adalag rata-rata 36 dengan persentase 64,29 masih kategori cukup. Berdasarkan dari persenatse dan 4 aspek yang diamati aspek yang mendapat nilai kurang baik tersebut, merupakan suatu kelemahan yang terjadi pada siklus I dan akan dijadikan bahan kajian untuk refleksi dan revisi yang akan dilakukan pada siklus II.

Hasil nilai tes formatif pada siklus I dapat dilihat pada table 4 di bawah ini:

Tabel 4. Nilai Tes Formatif Pada Siklus I

\begin{tabular}{|c|c|c|}
\hline $\begin{array}{c}\text { No. } \\
\text { Urut }\end{array}$ & Nilai & Keterangan \\
\hline \hline 1 & 70 & Tidak Tuntas \\
\hline 2 & 65 & Tuntas \\
\hline 3 & 75 & Tuntas \\
\hline 4 & 70 & Tuntas \\
\hline 5 & 60 & Tidak Tuntas \\
\hline 6 & 75 & Tuntas \\
\hline 7 & 80 & Tuntas \\
\hline 8 & 65 & Tidak Tuntas \\
\hline 9 & 85 & Tuntas \\
\hline 10 & 70 & Tuntas \\
\hline 11 & 60 & Tidak Tuntas \\
\hline 12 & 50 & Tidak Tuntas \\
\hline 13 & 70 & Tuntas \\
\hline 14 & 85 & Tuntas \\
\hline
\end{tabular}

\begin{tabular}{|c|c|c|}
\hline $\begin{array}{c}\text { No. } \\
\text { Urut }\end{array}$ & Nilai & Keterangan \\
\hline \hline 15 & 90 & Tuntas \\
\hline 16 & 80 & Tuntas \\
\hline 17 & 65 & Tidak Tuntas \\
\hline 18 & 75 & Tuntas \\
\hline 19 & 85 & Tuntas \\
\hline 20 & 85 & Tuntas \\
\hline 21 & 70 & Tuntas \\
\hline 22 & 60 & Tidak Tuntas \\
\hline 23 & 60 & Tidak Tuntas \\
\hline 24 & 70 & Tuntas \\
\hline 25 & 70 & Tuntas \\
\hline 26 & 70 & Tuntas \\
\hline 27 & 95 & \\
\hline
\end{tabular}

\begin{tabular}{rlr|}
\hline Jumlah Nilai $=$ & 1955 \\
Jumlah nilai Maksimal Ideal $=$ & 2700 \\
Rata-Rata Nilai Tercapai $=$ & 72,41 \\
\hline
\end{tabular}

Keterangan:

$$
\begin{array}{rll}
\text { Jumlah peserta didik yang belum tuntas } & = & 8 \\
\text { Jumlah peserta didik yang tuntas }= & 19 \\
\text { Klasikal }= & \text { Belum Tuntas }
\end{array}
$$

Tabel 5. Rekapitulasi Hasil Tes Formatif Pada Siklus I

\begin{tabular}{|c|l|c|}
\hline No. & \multicolumn{1}{|c|}{ Uraian } & Hasil Siklus I \\
\hline \hline 1. & Nilai rata-rata tes formatif & 72,41 \\
\hline 2. & Jumlah peserta didik yang tuntas belajar & 19 \\
\hline 3. & Persentase ketuntasan belajar & 70,37 \\
\hline
\end{tabular}

Kemudian, melihat dari tabel 4 dan 5 dapat dijelaskan bahwa dengan model pembelajaran kooperatif tipe round club diperoleh nilai rata-rata hasil belajar peserta didik adalah 72,41 dan ketuntasan belajar mencapai $70,37 \%$ atau ada 19 peserta didik dari 27 peserta didik sudah tuntas belajar. Hasil tersebut menunjukkan bahwa pada siklus pertama secara klasikal peserta didik belum tuntas belajar, karena peserta didik yang memperoleh nilai $\geq 75$ hanya sebesar $70,37 \%$ lebih kecil dari persentase ketuntasan yang dikehendaki yaitu sebesar $85 \%$. Hal ini disebabkan karena peserta didik masih merasa baru dan belum mengerti apa yang dimaksudkan dan digunakan guru dengan model pembelajaran kooperatif tipe round club.

\section{Siklus II}

\section{Tahap perencanaan}

Pada tahap ini peneliti mempersiapkan perangkat pembelajaran yang terdiri dari rencana pelajaran II, LKPD II, soal tes formatif II dan alat-alat pengajaran yang mendukung. Selain itu juga dipersiapkan lembar observasi pengelolaan model pembelajaran kooperatif tipe round club.

\section{Tahap kegiatan dan pelaksanaan}

Pelaksanaan kegiatan belajar mengajar untuk siklus II dilaksanakan pada tanggal 2 dan 9 Oktober 2017 di kelas IV.A dengan jumlah peserta didik 27 peserta didik. Dalam hal ini peneliti bertindak sebagai guru. Adapun proses belajar mengajar mengacu pada rencana pelajaran dengan memperhatikan revisi pada siklus I, sehingga kesalahan atau kekurangan pada siklus I tidak terulang lagi pada siklus II. Pengamatan (observasi) dilaksanakan bersamaan dengan pelaksanaan belajar mengajar.

Pada akhir proses belajar mengajar peserta didik diberi tes formatif II dengan tujuan untuk mengetahui tingkat keberhasilan peserta didik dalam proses belajar mengajar yang telah dilakukan. Instrumen yang digunakan adalah tes formatif II. Adapun data hasil penelitian pada siklus II adalah seperti yang terlihat pada tabel 6 
Tabel 6. Pengelolaan Pembelajaran Pada Siklus II

\begin{tabular}{|c|c|c|c|c|}
\hline \multirow{2}{*}{ No. } & \multirow{2}{*}{ Aspek Yang diamati } & \multicolumn{2}{|c|}{ Penilaian } & \multirow{2}{*}{ Rata-Rata } \\
\hline & & $\mathrm{P} 1$ & $\mathrm{P} 2$ & \\
\hline \multirow{14}{*}{ I. } & $\begin{array}{l}\text { Pengamatan KBM } \\
\text { A. Pendahuluan }\end{array}$ & & & \\
\hline & 1. Memotivasi peserta didik & 4 & 4 & 4 \\
\hline & 2. Menyampaikan tujuan pembelajaran & 4 & 4 & 4 \\
\hline & 3. Menghubungkan dengan pelajaran sebelumnya & 4 & 4 & 4 \\
\hline & 4. Mengatur peserta didik dalam kelompok-kelompok belajar & 4 & 4 & 4 \\
\hline & B. Kegiatan inti & & & \\
\hline & 1. Mempresentasikan langkah-langkah metode pembelajaran kooperatif & 3 & 4 & 3,5 \\
\hline & 2. Membimbing peserta didik melakukan kegiatan & 4 & 4 & 4 \\
\hline & 3. Melatih keterampilan kooperatif & 3 & 4 & 3,5 \\
\hline & 4. Mengawasi setiap kelompok secara bergiliran & 4 & 4 & 4 \\
\hline & 5. Memberikan bantuan kepada kelompok yang mengalami kesulitan & 4 & 4 & 4 \\
\hline & C. Penutup & & & \\
\hline & 1. Membimbing peserta didik membuat rangkuman & 4 & 4 & 4 \\
\hline & 2. Memberikan evaluasi & 4 & 4 & 4 \\
\hline II. & Pengelolaan Waktu & 3 & 4 & 3,5 \\
\hline \multirow{3}{*}{ III. } & Antusiasme Kelas & & & \\
\hline & 1. Peserta didik antusias & 4 & 4 & 4 \\
\hline & 2. Guru antusias & 4 & 4 & 4 \\
\hline \multicolumn{2}{|r|}{ Jumlah } & 53 & 56 & 54,5 \\
\hline & Keterangan: & $\begin{array}{c}\text { Nilai } \\
1 \\
2 \\
3 \\
4\end{array}$ & \multicolumn{2}{|c|}{$\begin{array}{l}\text { Kriteria } \\
\text { Tidak Baik } \\
\text { Kurang Baik } \\
\text { Cukup Baik } \\
\text { Baik }\end{array}$} \\
\hline
\end{tabular}

Dengan penyempurnaan aspek-aspek I atas alam penerapan Model pembelajaran kooperatif tipe Round club diharapkan peserta didik dapat menyimpulkan apa yang telah mereka pelajari dan mengemukakan pendapatnya sehingga mereka akan lebih memahami tentang apa yang telah mereka lakukan. Persetase hasil Pengelolaan Pembelajaran adalah dengan skor 54,5 dengan persentase $(97,32 \%)$

Hasil nilai tes formatif pada siklus II dapat dilihat pada tablel 7 di bawah ini:

Tabel 7. Nilai Tes Formatif Pada siklus II

\begin{tabular}{|c|c|c|}
\hline $\begin{array}{c}\text { No. } \\
\text { Urut }\end{array}$ & Nilai & Keterangan \\
\hline \hline 1 & 90 & Tuntas \\
\hline 2 & 80 & Tuntas \\
\hline 3 & 80 & Tuntas \\
\hline 4 & 75 & Tuntas \\
\hline 5 & 60 & Tidak Tuntas \\
\hline 6 & 85 & Tuntas \\
\hline 7 & 85 & Tuntas \\
\hline 8 & 80 & Tuntas \\
\hline 9 & 80 & Tuntas \\
\hline 10 & 85 & Tuntas \\
\hline 11 & 70 & Tidak Tuntas \\
\hline 12 & 70 & Tidak Tuntas \\
\hline 13 & 85 & Tuntas \\
\hline 14 & 90 & Tuntas \\
\hline
\end{tabular}

\begin{tabular}{|c|c|c|}
\hline $\begin{array}{c}\text { No. } \\
\text { Urut }\end{array}$ & Nilai & Keterangan \\
\hline \hline 15 & 90 & Tuntas \\
\hline 16 & 85 & Tuntas \\
\hline 17 & 80 & Tuntas \\
\hline 18 & 80 & Tuntas \\
\hline 19 & 90 & Tuntas \\
\hline 20 & 85 & Tuntas \\
\hline 21 & 80 & Tuntas \\
\hline 22 & 65 & Tidak Tuntas \\
\hline 23 & 80 & Tuntas \\
\hline 24 & 80 & Tuntas \\
\hline 25 & 90 & Tuntas \\
\hline 26 & 80 & Tuntas \\
\hline 27 & 85 & Tuntas \\
\hline
\end{tabular}


Tabel 8. Rekapitulasi Hasil Tes Formatif Pada Siklus II

\begin{tabular}{|c|l|c|}
\hline No. & \multicolumn{1}{|c|}{ Uraian } & Hasil Siklus II \\
\hline \hline 1. & Nilai rata-rata tes formatif & 80,93 \\
\hline 2. & Jumlah peserta didik yang tuntas belajar & 23 \\
\hline 3. & Persentase ketuntasan belajar & 85,19
\end{tabular}

Dari tabel 7 dan 8 di atas diperoleh nilai rata-rata hasil belajar peserta didik adalah 80,93 dan ketuntasan belajar mencapai $85,19 \%$ atau ada 23 peserta didik dari 27 peserta didik sudah tuntas belajar. Hasil ini menunjukkan bahwa pada siklus II ini ketuntasan belajar secara klasikal telah mengalami peningkatan sedikit lebih baik dari siklus I. Adanya peningkatan hasil belajar peserta didik ini karena setelah guru menginformasikan bahwa setiap akhir pelajaran akan selalu diadakan tes sehingga pada pertemuan berikutnya peserta didik lebih termotivasi untuk belajar. Selain itu peserta didik juga sudah mulai mengerti apa yang dimaksudkan dan diinginkan guru dengan menerapkan model pembelajaran kooperatif tipe round club.

\section{Pembahasan \\ Ketuntasan Hasil belajar Peserta didik}

Melalui hasil penelitian ini menunjukkan bahwa pembelajaran kooperatif tipe round club memiliki dampak positif dalam meningkatkan hasil belajar peserta didik. Hal ini dapat dilihat dari semakin mantapnya pemahaman peserta didik terhadap materi yang disampaikan guru terbukti dari ketuntasan belajar yang meningkat dari pra siklus sebesar $(51,85 \%)$, siklus I $(70,37 \%)$ dan siklus II(85,19\%). Pada siklus II ketuntasan belajar peserta didik secara klasikal telah tercapai. Berikut grafik peningkatan hasil belajar:

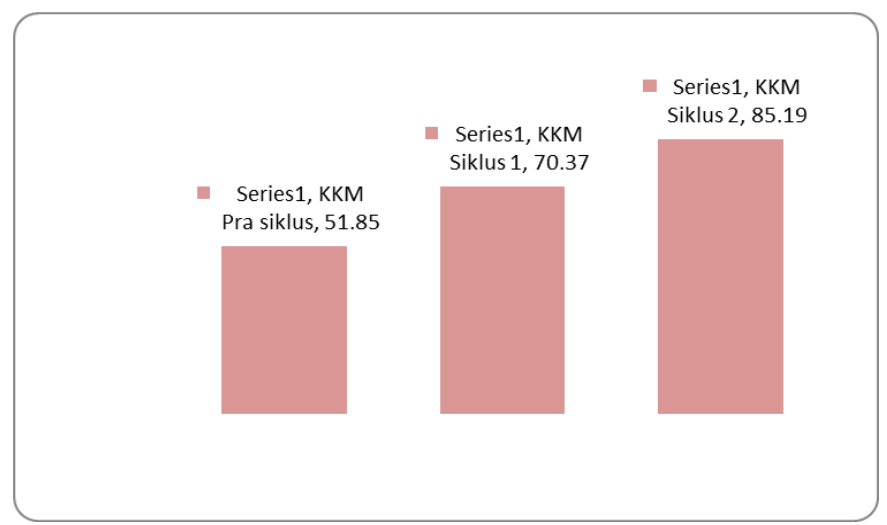

Gambar 1. Peningkatan Hasil Belajar

\section{Kemampuan Guru dalam Mengelola Pembelajaran}

Berdasarkan analisis data, diperoleh aktivitas peserta didik dalam proses model pembelajaran kooperatif tipe round club dalam setiap siklus mengalami peningkatan. Hal ini berdampak positif terhadap hasil belajar peserta didik yaitu dapat ditunjukkan dengan meningkatnya nilai rata-rata peserta didik pada setiap siklus yang terus mengalami peningkatan. Berikut grafik pengelolaan pembelajaran di kelas IV A SD Negeri 64/IV Jambi .

Hasil belajar dipengaruhi oleh pengelolaan pembelajaran yang dilakukan guru. Hasil pengelolaan pembelajaran guru setiap siklus mengalami peningkatan karena adanya perubahan yang dilakukan dalam pengelolaan pembelajaran. Hasil pengelolaan pembelajaran dapat dilihat pada gambar 2 sebagai berikut.

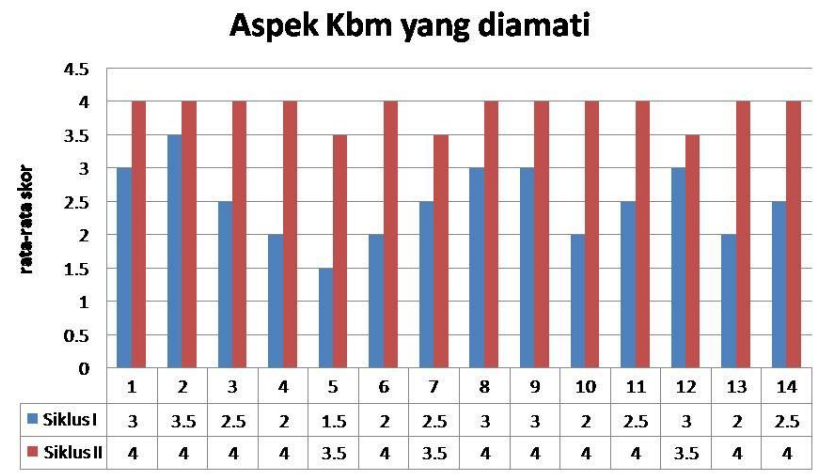

Gambar 2. Grafik Pengelolaan Pembelajaran

$\begin{aligned} & \text { Keterangan: } \\ & \text { Aspek KBM yang Diamati: } \\ & 1=\text { Memotivasi peserta didik } \\ & 2=\text { Menyampaikan tujuan pembelajaran } \\ & 3=\text { Menghubungkan dengan pelajaran sebelumnya } \\ & 4=\text { Mengatur peserta didik dalam kelompok- } \\ & 5=\text { Mempresentasikan langkah-langkah model } \\ & 6=\text { Membimbing peserta didik melakukan kegiatan } \\ & 7=\text { Melatih keterampilan belajar kelompok } \\ & 8=\text { Mengawasi setiap kelompok secara bergiliran } \\ & 9=\text { Memberikan bantuan kepada kelompok yang } \\ & 10=\text { Mengalami kesulitan } \\ & 11=\text { Membimbing peserta didik membuat } \\ & 12=\text { Pengelolaan Waktu } \\ & 13=\text { Peserta didik antusias } \\ & 14=\text { Guru antusias }\end{aligned}$

\section{SIMPULAN}

Dari hasil kegiatan pembelajaran yang telah dilakukan selama dua siklus, dan berdasarkan seluruh pembahasan serta analisis yang telah dilakukan dapat disimpulkan bahwa model pembelajaran round club memiliki dampak positif dalam meningkatkan hasil belajar PKn materi pokok mendeskripsikan negara kesatuan Republik Indonesia yang ditandai dengan peningkatan hasil belajar dan ketuntasan belajar peserta didik dalam setiap siklus. Untuk hasil belajar pada siklus I $(72,41)$ dan siklus II $(80,93)$ selanjutnya untuk ketuntasan hasil belajar yaitu pra siklus $(51,85 \%)$, siklus I $(70,37 \%)$, siklus II (85,19\%). Dengan demikian hasil belajar Pkn dengan materi Negara Kesatuan Rebuplik 
Indonesia siswa kelas IV.A dapat ditingkatkan dengan menggunakan model pembelajaran Round Club.

\section{DAFTAR PUSTAKA}

A. Tabrani Rusyan, dkk, 1992. Pendekatan dalam Proses Belajar Mengajar, Remaja Karya: Bandung

Aminuddin, 2011. Semanttik. Bandung. CV Sinar Baru Algesindo

A.M, Sardiman. 2003. Interaksi dan Motivasi Belajar Mengajar. PT Raja Grafindo Persada. Jakarta.

Dimyati dan Mudjiono. 2006. Belajar dan Pembelajaran. Jakarta: PT. Rineka Cipta.

Hamalik, Oemar. 2008. Kurikulum dan Pembelajaran. Bumi Aksara.

Hamalik, Oemar. 2008. Pendidikan Guru Berdasarkan Pendekatan Kompetensi. Bumi Aksara.

Hamalik, Oemar. 2008. Perencanaan Pengajaran Berdasarkan Pendekatan Sistem. Bumi Aksara.

Hamalik, Oemar. 2008. Proses Belajar Mengajar. Bumi Aksara.

Hanafiah, Nanang dan Cucu Suhana (2009), Konsep Strategi Pembelajaran. Bandung: PT. Refika Aditama

Hasan, Chalijah, 1994. Dimensi-Dimensi Psikologi Pendidikan, Al Ikhlas: Surabaya

Mudjiono, Dimyati.2009.Belajar dan Pembelajaran. Jakarta:Rineka Cipta

Tim Pustaka Yustisia, 2008, Panduan Lengkap KTSP (Kurikulum Tingkat Satuan Pendidikan), Yogyakarta; Pustaka Yustisia.

Winataputra, dkk. 2007. Teori Belajar dan Pembelajaran. Universitas Terbuka. Jakarta. 